\title{
EFFECT OF DEPRESSANTS AND BASE METAL ON MICROSTRUCTURE OF BRAZED SEAMS IN JOINTS OF Ni3Al-BASED ALLOYS WITH Inconel 718 ALLOY
}

\author{
S.V. MAKSYMOVA, V.F. KHORUNOV and V.V. MYASOEDOV \\ E.O. Paton Electric Welding Institute, NASU \\ 11 Bozhenko Str., 03680, Kiev, Ukraine. E-mail: office@paton.kiev.ua
}

\begin{abstract}
Properties of brazed joints are caused by their microstructure. Therefore, metallographic and X-ray microspectral analysis of brazed joints have large importance in selection of composition of brazing filler metal and parameters of technological mode of brazing. Relevance of such investigations rises in development of technological processes for brazing of the joints from materials of new generation, to which nickel alloys based on $\gamma^{\prime}$-Ni3Al intermetallic can be referred. This paper represents the results of metallographic and $\mathrm{X}$-ray microspectral analysis of the brazed joints from heat-resistant nickel alloy based on $\mathrm{Ni} 3 \mathrm{Al}$ intermetallic with Inconel 718 grade wrought alloy produced with the $\mathrm{Ni}-\mathrm{Cr}-\mathrm{Fe}-\mathrm{B}-\mathrm{Si}$ and $\mathrm{Ni}-\mathrm{Pd}-\mathrm{Cr}-\mathrm{X}(\mathrm{Ge}, \mathrm{Co})$ system brazing filler metals. Effect of depressants, i.e. boron and silicon, on formation of structure in seams is shown. Influence of constituents of material being brazed on composition and morphology of seam is determined. It is found that brazing of $\mathrm{Ni} 3 \mathrm{Al}$-based alloy using $\mathrm{Ni}-\mathrm{Pd}-\mathrm{Cr}-\mathrm{X}(\mathrm{Ge}, \mathrm{Co})$ brazing filler metal provides for seam structure consisting of solid solution based on nickel and single dispersed phases. The latter are enriched with $(\mathrm{Pd}, \mathrm{X}) \mathrm{Al}$ type aluminum, a concentration of which corresponds to aluminum concentration in the base metal. Their formation takes place due to diffusion processes at interface. Single-phase areas consisting of nickel-based solid solution are observed in the brazed seam. 12 Ref., 6 Tables, 7 Figures.
\end{abstract}

Key words: vacuum brazing, heat-resistant $\mathrm{Ni} 3 \mathrm{Al}$ based alloy, microstructure, seam, X-ray microspectral analysis, solid solution, brazing filler metal

Brazing finds wide application in number of branches of industry due to possibility to preserve base metal structure (since only brazing filler metal (BFM), which has lower melting temperature, is melted) and join materials in difficultto-reach places [1-3]. Number of BFMs exist at present time. However, each material being brazed requires individual approach in selection of composition of BFM. It is caused by its structural peculiarities, specific operation conditions and required mechanical properties of the brazed joints. Brazed joint structure is determined by seam structure. Therefore, large attention is paid to metallographic and X-ray microspectral analysis of the brazed joints, which stipulate choice of BFM composition and parameters of technological mode of brazing [4]

Relevance of such investigations increases in development of technological processes for production of the brazed joints from new generation materials, to which alloys based on $\gamma^{\prime}-\mathrm{Ni}_{3} \mathrm{Al}$ intermetallic are referred. $\mathrm{Ni}_{3} \mathrm{Al}$ intermetallic bond has high melting temperature $\left(1385^{\circ} \mathrm{C}\right)$, reduced density $\left(7.5 \mathrm{~kg} / \mathrm{m}^{3}\right)$ and thermal stability of structure up to melting temperature $[5,6]$.

This work represents the results of metallographic and X-ray microspectral analysis on study the effect of base metal composition $\left(\mathrm{Ni}_{3} \mathrm{Al}-\right.$ based alloy) and depressants (boron) on structure and morphological structure of the brazed joints produced using $\mathrm{Ni}-\mathrm{Cr}-\mathrm{Fe}-\mathrm{B}-\mathrm{Si}$ and $\mathrm{Ni}-$ $\mathrm{Pd}-\mathrm{Cr}-\mathrm{X}(\mathrm{Ge}, \mathrm{Co})$ system BFMs. Nickel heatresistant alloys based on $\mathrm{Ni}_{3} \mathrm{Al}$ intermetallic in

Table 1. Base metal composition investigated

\begin{tabular}{||c|c|c|c|c|c|c|c|c|c|c||}
\hline \hline \multirow{2}{*}{ Alloy grade } & \multicolumn{10}{|c|}{ Weight fraction of chemical elements, \% } \\
\cline { 2 - 20 } & $\mathrm{Ni}$ & $\mathrm{Al}$ & $\mathrm{Cr}$ & $\mathrm{Nb}$ & $\mathrm{Mo}$ & $\mathrm{Si}$ & $\mathrm{Ti}$ & $\mathrm{W}$ & $\mathrm{Fe}$ & $\mathrm{C}$ \\
\hline $\mathrm{Ni}_{3} \mathrm{Al}(1)$ & Base & 10 & 4 & - & - & 1.5 & 1 & 3 & - \\
\hline $\mathrm{Ni}_{3} \mathrm{Al}(2)$ & Base & 9 & - & - & 18 & - & - & - & - & - \\
\hline Inconel 718 & 53 & 0.8 & 19 & 5.5 & 3.3 & - & 0.95 & - & 18 & 0.08 \\
\hline
\end{tabular}




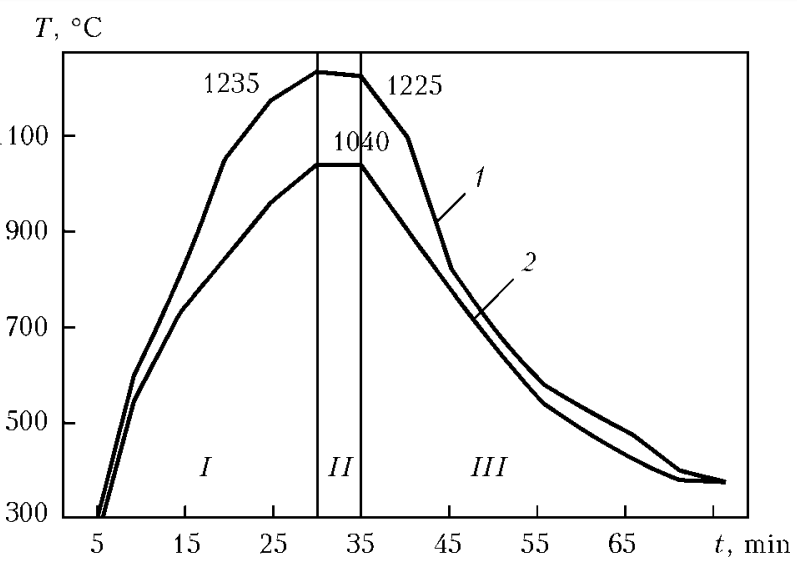

Figure 1. Curves of thermal cycle of specimen brazing: 1 palladium BFM; 2 - B-containing BFM; $I$ - heating; $I I$ - holding, $I I I$ - cooling

similar and dissimilar combinations with wrought nickel alloy Inconel 718 (Table 1) were used as base metal for experiments.

Vacuum brazing of specimen lap joints was carried out in vacuum furnace $\left(1.33 \cdot 10^{-4} \mathrm{~Pa}\right)$ with radiation heating. $\mathrm{Ni}_{3} \mathrm{Al}$-based nickel alloy and wrought alloy Inconel 718 was brazed by palladium $\mathrm{Ni}-\mathrm{Pd}-\mathrm{Cr}-\mathrm{X} \mathrm{BFM}$ using mode 1 and B-containing BFM BMF-20 ( $\mathrm{Ni}-\mathrm{Cr}-\mathrm{Fe}-\mathrm{B}-\mathrm{Si})$ using mode 2 (Figure 1).

Microsections of the brazed joints were manufactured by standard procedure for performance of metallographic and X-ray microspectral analysis using electron scanning microscope TescanMira 3 LMU equipped with Oxford Instruments energy-dispersive spectrometer $\mathrm{X}$-max $80 \mathrm{~mm}^{2}$ (with INCA software). Locality of X-ray microspectral analysis did not exceed $1 \mu \mathrm{m}$. Distribution of chemical elements and exposure of microstructures were carried out using back-side illumination mode (BSI) allowing differentiating structural constituents by atomic mass (without chemical etching).

Visual examination of received specimens in both cases showed good wetting of the materials
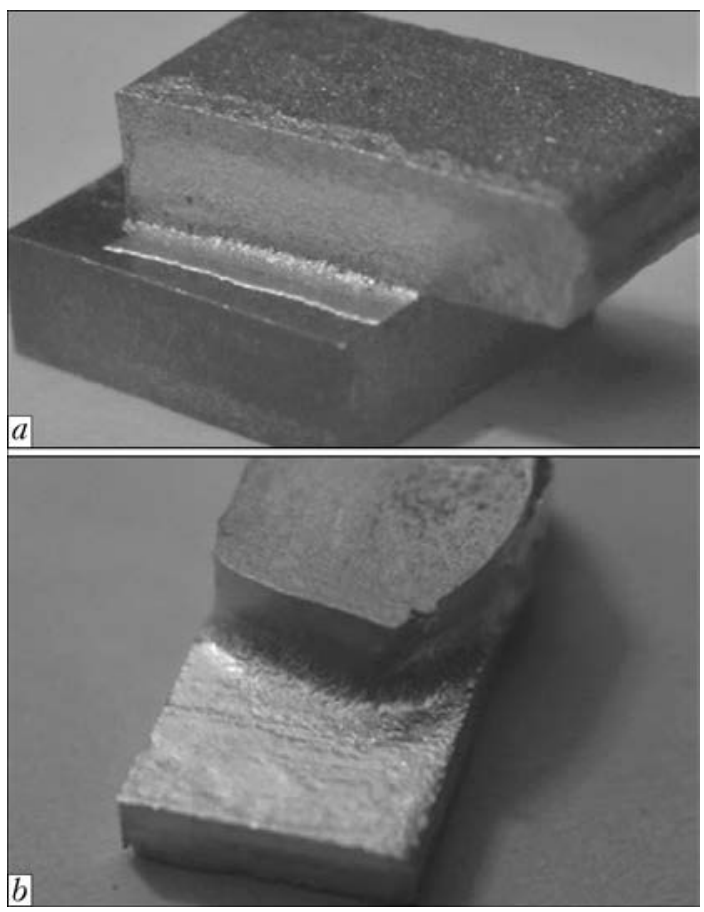

Figure 2. View of $\mathrm{Ni}_{3} \mathrm{Al}+$ Inconel 718 brazed specimens produced using BFMs of $\mathrm{Ni}-\mathrm{Cr}-\mathrm{Fe}-\mathrm{B}-\mathrm{Si}(a)$ and $\mathrm{Ni}-\mathrm{Pd}-$ $\mathrm{Cr}-\mathrm{X}(b)$ system

being brazed by BFM, filling of the clearances and formation of full fillets (Figure 2).

Metallographic examinations showed that the dark phase acicular particles (Figure $3, a-c$ ) can be observed in the seam and base Inconel 718 metal against light matrix background when using $\mathrm{Ni}-\mathrm{Cr}-\mathrm{Fe}-\mathrm{B}-\mathrm{Si}$ system $\mathrm{BFM}$. Examination of element composition distribution in local areas of the brazed joint was carried out with the help of X-ray microspectral analysis. It revealed increased concentration of chromium in these particles (Figure 3, $d$; Table 2, spectrum 1 and 2). Their precipitation is mainly observed in a zone of Inconel 718 alloy (lower specimen) adjacent to the seam and at interface in the seam zone.

Examination of change of element concentration along the scanning line, passing through this

Table 2. Distribution of elements in brazed seam of $\mathrm{Ni}_{3} \mathrm{Al}+$ Inconel 718 joint (acc. to Figure 3 )

\begin{tabular}{|c|c|c|c|c|c|c|c|c|c|}
\hline \multirow{2}{*}{$\begin{array}{l}\text { Spectrum } \\
\text { number }\end{array}$} & \multicolumn{9}{|c|}{ Chemical elements, wt.\% } \\
\hline & $\mathrm{Al}$ & $\mathrm{Si}$ & $\mathrm{Ti}$ & $\mathrm{Cr}$ & $\mathrm{Fe}$ & $\mathrm{Ni}$ & $\mathrm{Nb}$ & Mo & $\mathrm{W}$ \\
\hline 1 & 1.14 & 2.47 & 0.32 & 24.78 & 6.45 & 60.30 & 1.09 & 3.46 & - \\
\hline 2 & 0.61 & 1.50 & 0.25 & 37.93 & 5.81 & 47.45 & 0.76 & 4.68 & 1.01 \\
\hline 3 & 0.91 & 1.34 & 0.18 & 53.37 & 3.33 & 38.67 & 0.50 & 0.92 & 0.78 \\
\hline 4 & 16.13 & 1.71 & 0.09 & 4.99 & - & 76.62 & 0 & 0 & 0.46 \\
\hline 5 & 2.32 & 2.30 & 0.36 & 7.25 & 5.07 & 79.97 & 1.42 & 0.57 & 0.73 \\
\hline 6 & 9.59 & 0.62 & 1.12 & 3.76 & - & 82.65 & - & - & 2.27 \\
\hline 7 & 0.51 & 0.89 & 0.67 & 18.77 & 13.70 & 57.48 & 4.69 & 3.29 & - \\
\hline 8 & 1.93 & 2.39 & 0.40 & 13.16 & 5.49 & 74.88 & 1 & 0.29 & 0.45 \\
\hline 9 & 10.16 & 1.02 & 1.44 & 4.76 & 0.17 & 79.53 & - & - & 2.92 \\
\hline 10 & 0.45 & 0.14 & 0.90 & 19.69 & 17.16 & 51.88 & 5.91 & 3.87 & - \\
\hline
\end{tabular}




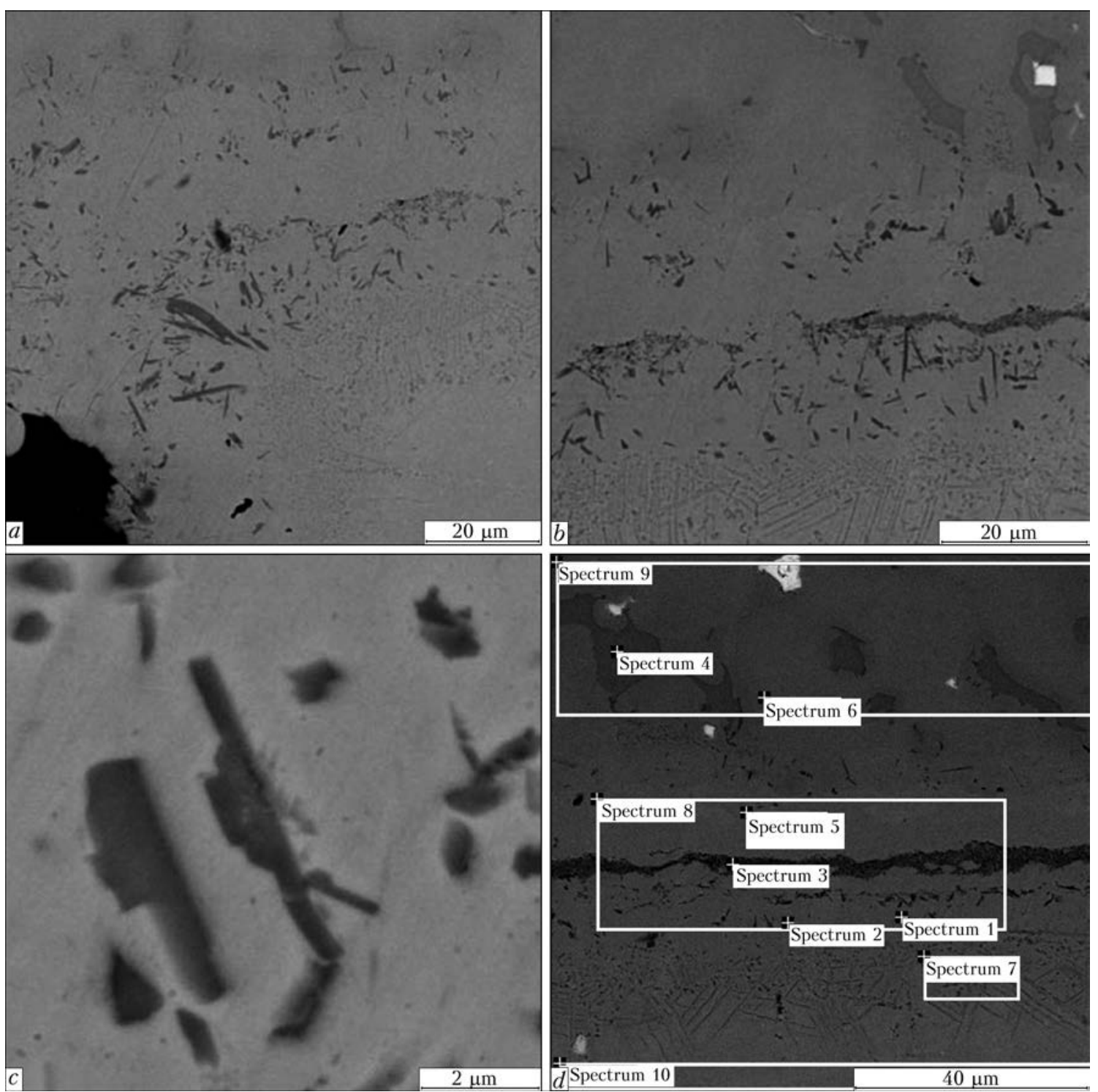

Figure 3. Microstructure of $\mathrm{Ni}_{3} \mathrm{Al}+$ Inconel 718 dissimilar brazed joint produced using $\mathrm{B}$-containing $\mathrm{BFM}$ of $\mathrm{Ni}-\mathrm{Cr}-$ Fe-B-Si system: $a-$ fillet area; $b-$ seam; $c$ - chromium borides; $d-$ examined areas

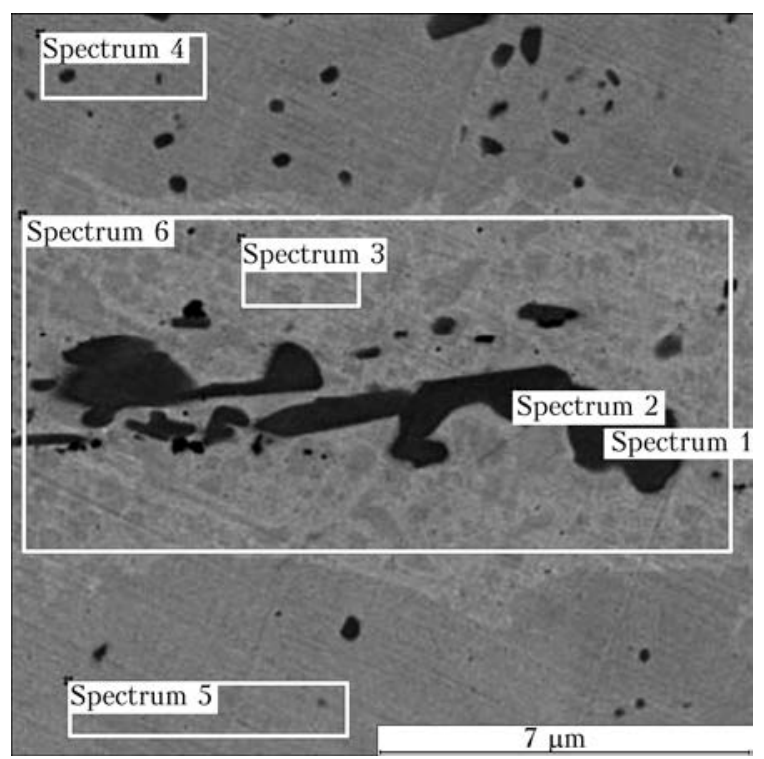

Figure 4. Microstructure of $\mathrm{Ni}_{3} \mathrm{Al}$ similar joint produced using B-containing BFM particle, showed increased content of boron and simultaneous reduction of nickel content. It indicates formation of B-containing phase. This can be explained by high chromium concentration (19\%) in brazed Inconel 718 in comparison with $\mathrm{Ni}_{3} \mathrm{Al}-$ based alloy ( $4 \%)$, that allows additional input of chromium in liquid BFM (during brazing) and assists active formation and precipitation of chromium borides. Amount of such precipitates is insignificant (Figure 3, $a, b$ ) at the interface with $\mathrm{Ni}_{3} \mathrm{Al}$-based nickel alloy (upper specimen).

Examination of chemical inhomogeneity of the brazed joints showed that increased concentration of chromium $(24.78-37.93 \%)$ is observed in acicular-like particles in the seam zone from Inconel 718 side and in the seam central zone (Figure 3, $d$; Table 2). In the latter case the Cr-based phase precipitates in a continuous band form. Such structural peculiarities have negative effect on properties of the brazed joints. 
Table 3. Distribution of elements in $\mathrm{Ni}_{3} \mathrm{Al}+\mathrm{Ni}_{3} \mathrm{Al}$ brazed joint (acc. to Figure 4)

\begin{tabular}{|c|c|c|c|c|c|c|c|c|}
\hline \multirow{2}{*}{$\begin{array}{l}\text { Spect- } \\
\text { rum } \\
\text { number }\end{array}$} & \multicolumn{8}{|c|}{ Chemical elements, wt.\% } \\
\hline & $\mathrm{B}^{*}$ & $\mathrm{Al}$ & $\mathrm{Si}$ & $\mathrm{Ti}$ & $\mathrm{Cr}$ & $\mathrm{Fe}$ & $\mathrm{Ni}$ & $\mathrm{W}$ \\
\hline 1 & 11.62 & - & - & - & 81.97 & - & 3.27 & 3.14 \\
\hline 2 & 6.58 & 2.37 & 1.16 & - & 37.70 & 1.66 & 48.72 & 1.81 \\
\hline 3 & - & 3.04 & 1.73 & 0.42 & 6.01 & 2.53 & 86.27 & - \\
\hline 4 & - & 5.83 & 1.69 & 0.31 & 3.54 & 1.06 & 86.95 & 0.62 \\
\hline 5 & - & 6.41 & 1.61 & 0.85 & 2.72 & 1.25 & 85.01 & 2.15 \\
\hline 6 & - & 2.86 & 1.55 & - & 15.91 & 2.41 & 76.57 & 0.70 \\
\hline
\end{tabular}

Brazing of nickel aluminides in similar combination (at the same mode) provokes precipitation of coarse dark particles based on nickel and chromium, enriched with boron (Figure 4; Table 3$)$, in the seam central zone.

Received examination results show that two types of borides, i.e. Ni- and Cr-based ones, are formed in brazing. Scanning along the line normal to the seam reveals increase of concentration of boron and chromium in the central zone ( $\mathrm{Fi}$ gure 5) and, respectively, decrease of nickel concentration. It is in good agreement with previous results and being an evidence of presence of boride phases in the seam center.

Similar formation of the brazed seams and element distribution is observed in brazing of stainless steel by B-containing BFMs [7, 8]. In brazing, boron actively diffuses from the seam in stainless steel, and B-containing phases precipitate at the interface of base metal grains. Presence of such a phase has negative effect on mechanical properties and corrosion resistance of the brazed joints. Formation of fusible boride eutectics and silicides in the seams and material being brazed have negative effect on long-term strength at elevated temperature [9].

In this connection further investigations are directed on elimination of formation of brittle phases in the brazed joint. For this, pilot palladium BFM based on solid solution without boron and silicon was used. Germanium, having large solubility range in nickel in comparison to silicon [10], was used as a depressant. In the initial cast state, the microstructure of given BFM consists of matrix, i.e. Ni-based solid solution, and phase dispersed Pd-based particles enriched with germanium.

Microstructure of the seams in joints from $\mathrm{Ni}_{3} \mathrm{Al}$ + Inconel 718, produced with palladium BFM on mode 1 (see Figure 1), consists of the Ni-based solid solution and Pd-based dispersed phase, enriched by aluminum up to $9.71 \%$ (Figure $6, a$; Table 4). Amount of this phase at the background of the brazed seam is insignificant, it precipitates in form of single dispersed particles (areas of up to
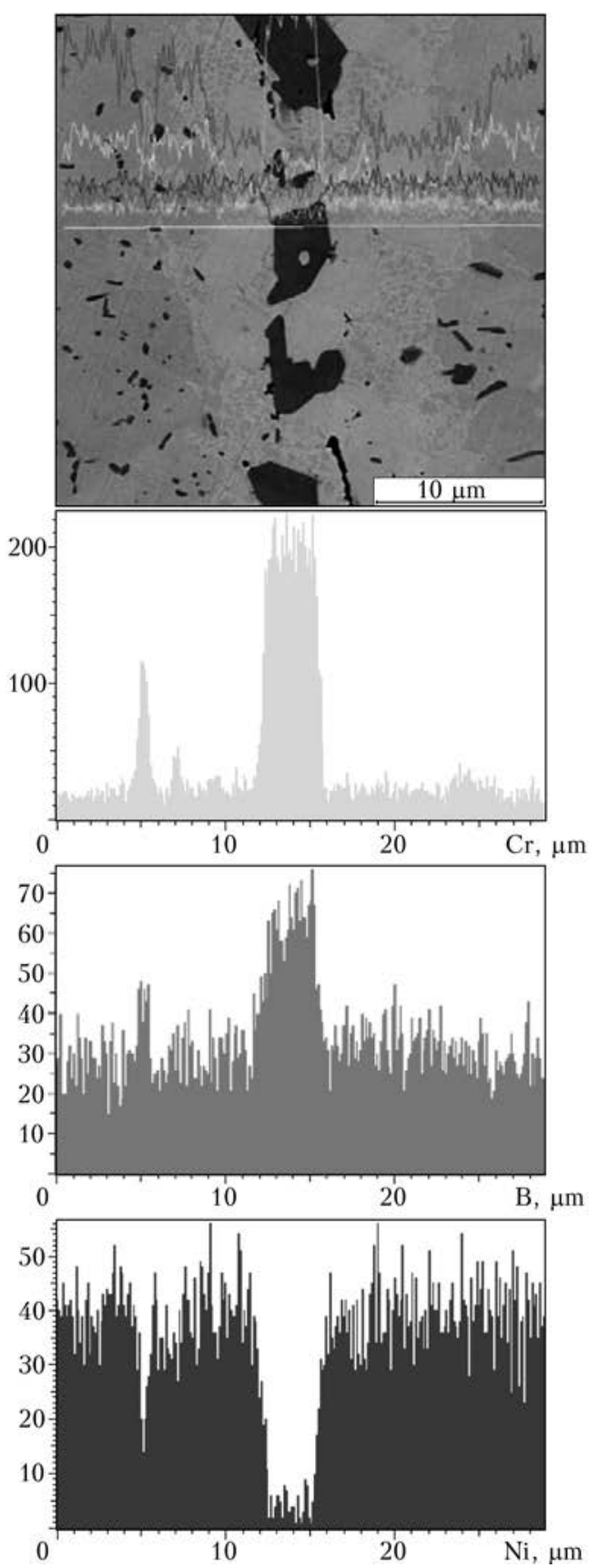

Figure 5. Distribution of BFM constituents along the scanning line of $\mathrm{Ni}_{3} \mathrm{Al}+\mathrm{Ni}_{3} \mathrm{Al}$ joint produced using B-containing BFM

$20 \mu \mathrm{m}$ size) in the solid solution matrix and can play a role of secondary strengthening phase.

Insignificant amount of constituents from materials being brazed are found in the Ni-based solid solution. Thus, concentration of iron makes $6.99 \%$ and aluminum does not exceed $1.78 \%$. It is explained by presence of concentration gradients at the interface, resulting in seam metal saturation with constituents of the base metal $[11,12]$. It should be noted that germanium is found only in the solid solution, and its concentration does not exceed $0.54 \%$.

In some sections the seam is difficult for visualization and clarified band serves as a Ni-based solid solution containing constituents of the 


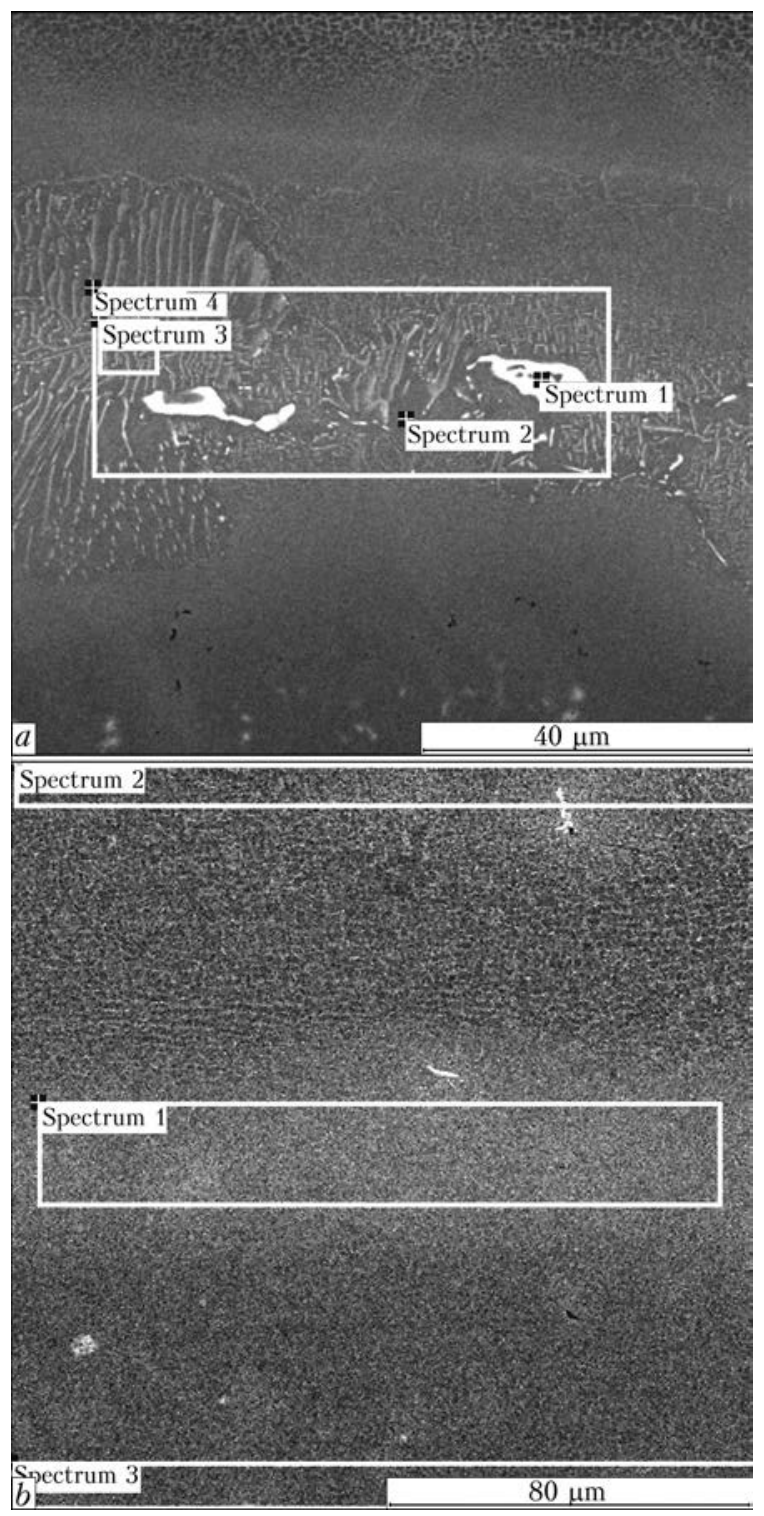

Figure 6. Examined sections of $\mathrm{Ni}_{3} \mathrm{Al}+$ Inconel 718 brazed joint produced using palladium BFM: $a-$ double-phase brazed seam with Pd-based phase; $b$ - single-phase seam with solid solution structure

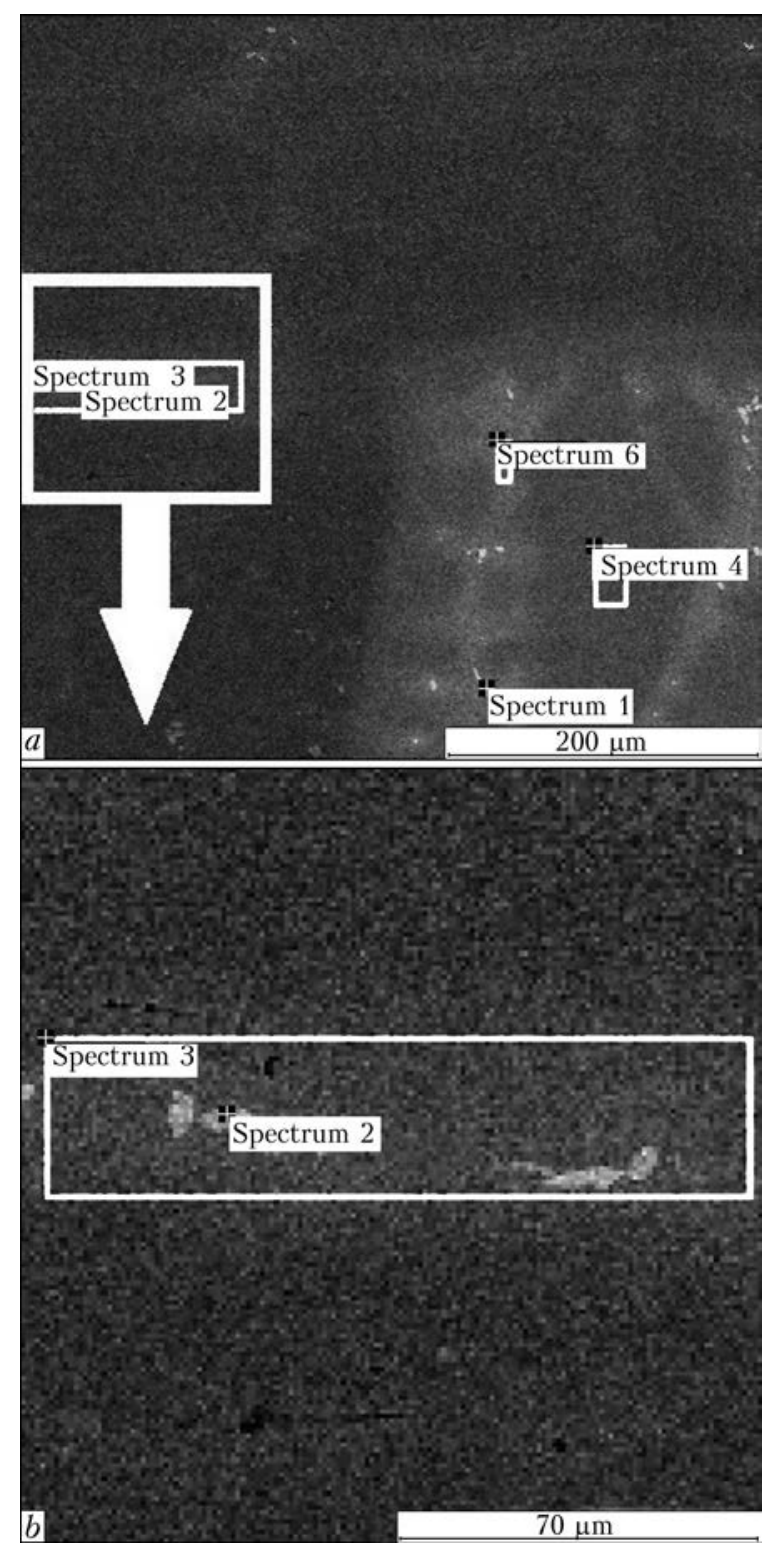

Figure 7. Microstructure of fillet section of $\mathrm{Ni}_{3} \mathrm{Al}+$ Inconel 718 brazed joint produced using palladium BFM $(a)$, and part of seam at larger magnification $(b)$

Table 4. Results of X-ray microspectral analysis of seam metal in $\mathrm{Ni}_{3} \mathrm{Al}+$ Inconel 718 brazed joint produced using palladium $\mathrm{BFM}$ (acc. to Figure 6, $a$ )

\begin{tabular}{|c|c|c|c|c|c|c|c|c|c|c|c|}
\hline \multirow{2}{*}{$\begin{array}{l}\text { Spectrum } \\
\text { number }\end{array}$} & \multicolumn{11}{|c|}{ Chemical elements, wt.\% } \\
\hline & $\mathrm{Al}$ & $\mathrm{Si}$ & $\mathrm{Ti}$ & $\mathrm{Cr}$ & $\mathrm{Fe}$ & Co & $\mathrm{Ni}$ & Ge & $\mathrm{Nb}$ & Mo & $\mathrm{Pd}$ \\
\hline 1 & 9.71 & - & 0.29 & 0.62 & 0.38 & - & 6.57 & - & - & - & 82.43 \\
\hline 2 & 0.99 & 0.13 & 0.71 & 13.64 & 6.99 & 1.08 & 53.53 & 0.54 & 4.89 & 4.79 & 12.70 \\
\hline 3 & 1.78 & 0.14 & 0.60 & 12.57 & 6.42 & 1.11 & 49.19 & 0.39 & 4.63 & 4.41 & 18.76 \\
\hline 4 & 2.23 & 0.12 & 0.50 & 12.06 & 6.08 & 1.13 & 48.23 & 0.26 & 4.06 & 4.63 & 20.69 \\
\hline
\end{tabular}

Table 5. Distribution of elements in section of seam with solid solution structure in $\mathrm{Ni}_{3} \mathrm{Al}+$ Inconel 718 brazed joint (acc. to Figure $6, b$ )

\begin{tabular}{||c|c|c|c|c|c|c|c|c|c|c||}
\hline \hline \multirow{2}{*}{$\begin{array}{c}\text { Spectrum } \\
\text { number }\end{array}$} & \multicolumn{10}{|c|}{ Chemical elements, wt.\% } \\
\cline { 2 - 23 } & $\mathrm{Al}$ & $\mathrm{Si}$ & $\mathrm{Ti}$ & $\mathrm{Cr}$ & $\mathrm{Fe}$ & $\mathrm{Co}$ & $\mathrm{Ni}$ & $\mathrm{Nb}$ & $\mathrm{Mo}$ & $\mathrm{Pd}$ \\
\hline 1 & 3.34 & 0.08 & 0.45 & 10.24 & 5.82 & 0.80 & 59.24 & 2.63 & 9.76 & 7.64 \\
\hline 2 & 7.16 & - & - & - & - & - & 75.65 & - & 17.01 & 0.18 \\
\hline 3 & 0.59 & 0.12 & 0.92 & 19.16 & 16.53 & - & 52.15 & 6.43 & 3.76 \\
\hline
\end{tabular}


Table 6. Results of X-ray microspectral analysis of seam fillet section in $\mathrm{Ni}_{3} \mathrm{Al}+$ Inconel 718 brazed joint (acc. to Figure 7 )

\begin{tabular}{|c|c|c|c|c|c|c|c|c|c|c|c|}
\hline \multirow{2}{*}{$\begin{array}{l}\text { Spectrum } \\
\text { number }\end{array}$} & \multicolumn{11}{|c|}{ Chemical elements, wt.\% } \\
\hline & $\mathrm{Al}$ & $\mathrm{Si}$ & $\mathrm{Ti}$ & $\mathrm{Cr}$ & $\mathrm{Fe}$ & $\mathrm{Co}$ & $\mathrm{Ni}$ & Ge & $\mathrm{Nb}$ & Mo & $\mathrm{Pd}$ \\
\hline 1 & 9.23 & 0.14 & 0.37 & 0.54 & 0.38 & - & 4.27 & - & - & - & 85.06 \\
\hline 2 & 13.10 & 0.08 & 0.26 & 1.97 & 1.57 & 0.15 & 14.44 & - & - & - & 68.44 \\
\hline 3 & 3.46 & 0.10 & 0.50 & 10.51 & 6.36 & 0.64 & 54.37 & 0.21 & 3.22 & 7.42 & 13.20 \\
\hline 4 & 0.65 & - & 0.25 & 16.45 & 7.60 & 1.66 & 52.18 & - & 2.10 & 3.78 & 15.32 \\
\hline 5 & 1.31 & 0.20 & 0.94 & 12.39 & 6.18 & 0.91 & 41.78 & 0.67 & 6.47 & 2.18 & 26.97 \\
\hline
\end{tabular}

BFM and material being brazed. Aluminum concentration rises from zero to $3.34 \%$ in the solid solution, while it amount makes $7.16 \%$ in the material being brazed (Figure $6, b$; Table 5).

Formation of similar structure (as in the seam), i.e. Ni-based solid solution and dispersed precipitates of Pd-based phase (Figure 6, $a, b$ ), are observed in the fillet sections. Difference is found in aluminum concentration, namely it is large in palladium phase of the seam and makes $13.10 \%$ in comparison with $9.23 \%$ of aluminum concentration in the similar phase in the fillet section (Figure 7, Table 6). Intensity and rate of growth of this phase are determined by diffusion coefficients for each element [11, 12]. Large extension of interface in the seam and narrow gap between metals being brazed provide for more favorable conditions for diffusion processes, that promotes active saturation of the seam metal by aluminum.

It is known that strength of the brazed joints and their service characteristics are determined by strength of interface bonds of the BFM elements with base metal elements. In other words, if strong bonds, mainly solid solutions, are formed in the seam, then they provide for larger strength than coarse boride phases. It should be underlined that diffusion layers and intermetallic phases in form of continuous bands along the seam, which can reduce properties of the brazed joints, are not formed in brazing by palladium BFM.

It is determined that chromium borides are formed in the seam and diffusion areas in brazing of heat-resistant nickel alloys based on $\mathrm{Ni}_{3} \mathrm{Al}$ intermetallic between themselves and their brazing to wrought nickel alloy of Inconel 718 grade with B-containing BFM.

Dense defect-free seams were produced using BFM based on $\mathrm{Ni}-\mathrm{Pd}-\mathrm{Cr}-\mathrm{X}(\mathrm{Ge}, \mathrm{Co})$ system. Interesting fact was found during composition examination that microstructure of the seam and initial BFM differ not only by chemical composition, but morphological structure as well. It is caused by presence of concentration gradient at the interface of material being brazed and liquid BFM, different value of diffusion coefficients of separate elements and non-equilibrium condi- tions of seam metal solidification resulting in active diffusion processes during brazing. The seam consists of Ni-based solid solution and single precipitates of dispersed $\mathrm{Pd}(\mathrm{X}) \mathrm{Al}$ phase, enriched with aluminum (9.71-13.10\%), in use of palladium BFM without aluminum for brazing of nickel aluminide. Morphological peculiarities of this phase can have positive effect on mechanical properties of the brazed joints. Study of mechanism of this process requires of additional detailed researches.

1. Khorunov, V.F. (2008) Principles of brazing of thinwall structures from high-alloy steels. Kiev: Naukova Dumka.

2. Radzievsky, V.N., Tkachenko, G.G. (2009) Vacuum brazing in compressor engineering. Kiev: Ekotekhnologiya.

3. Khorunov, V.F., Maksymova, S.V. (2013) Brazing of superalloys and the intermetallic alloy $(\gamma-T i A l)$. Advanced in brazing. Science, technology and applications, 85-120. Cambridge: Woodhead Publ.

4. Riggs, B., Alexandrov, B., Benatar, A. et al. (2015) Microstructural characterization of single crystal superalloy CMSX-4 brazed joints with BNi-2 and BNi-9 filler metals. IBSC-2015.

5. Grinberg, B.A., Ivanov, M.A. (2002) Intermetallics $\mathrm{Ni}$ Al: Microstructure, deformation behavior. Ekaterinburg: UrO RAN.

6. Kolobov, Yu.R., Kablov, E.N., Kozlov, E.V. et al. (2008) Structure and properties of intermetallic materials with nanophase strengthening. Moscow: MISiS.

7. Rabinkin, A. (2013) Brazing of superalloys and the intermetallic alloy $(\gamma-T i A l)$. Advanced in brazing. Science, technology and applications, 121. Cambridge: Woodhead Publ.

8. Maksymova, S.V. (2007) Amorphous braze filler metals for brazing of stainless steel with titanium and structure of brazed joints. Adgeziya Rasplavov $i$ Pajka Materialov, 40, 70-81.

9. Malashenko, I.S., Kurenkova, V.V., Belyavin, A.F. et al. (2006) Short-time strength and microstructure of brazed joints of alloy VJL12U produced using boron-containing brazing filler metal with addition of silicon. Advances in Electrometallurgy, 4, 23-38.

10. Massalski, T.V. (1990) ASM binary alloy phase diagrams. Metals Park: ASM Int.

11. Maksymova, S.V., Khorunov, V.F. (2015) Diffusion processes and formation of structure of brazed joints on titanium aluminides. J. Appl. Phys. Sci. Int., 2(1), 24-29.

12. Larikov, L.N., Isajchev, V.I. (1987) Structure and properties of metals and alloys: Refer. Book on diffusion in metals and alloys. Ed. by A.I. Rajchenko. Kiev: Naukova Dumka. 